\title{
STRATEGY FOR BUSINESS PORTFOLIO DEVELOPMENT OF PT SEKAR LAUT, TBK.
}

\author{
Homisah $^{* 1}$, Idqan Fahmi**), and Ahmad Mukhlis Yusuf***)
}

\author{
*) PT Perusahaan Industri Ceres \\ Jl Raya Narogong Km 7, Bojong Menteng, Rawalumbu, Bekasi, 17117 \\ ${ }^{* *}$ Department of Economics, Faculty of Economics and Management, Bogor Agricultural University \\ Jl. Kamper, Wing 4 Level 5, Campus IPB Dramaga, Bogor 16680 \\ ${ }^{* * *}$ Binus Business School
}

The Joseph Wibowo Center, Hang Lekir I No. 6, Senayan, Jakarta 10270

\begin{abstract}
PT Sekar Laut, Tbk. (PTSL), as a local company, has three main business units including snack crackers, cooking spices and private label. Due to the potentials of Indonesia, it is expected that PTSL can upscale its competitive advantage and has an ability to compete with global companies as well. The objectives of this research were 1) analyzing relative positioning of PTSL compared with market leaders in snack and cooking spices industries, 2) analyzing Life Cycle phase per business unit, 3) analyzing positioning of each product category in portfolio matrix, 4) formulating strategic recommendations to the management for each product category of PTSL. The method used in this study was descriptive analysis. The analysis tools used in this study were BCG matrix, Life Cycle model, IFE, IFI and GE matrix. The results showed that relative positioning of crackers and cooking spices business units in BCG matrix is in Question Marks quadrant. The results of Life Cycle model for snack crackers, cooking spices, and private label showed that they are in Growth phase. The result of portfolio analysis by GE matrix showed that shrimp cracker and fish cracker product categories are in Selective Growth quadrant. Vegetables cracker, cooking spices, uleg chili sauce, burger buns are in Investment and Growth quadrant. The strategic recommendation for shrimp and fish crackers is to identify the growth segment, aggressive investment and uphold position. The strategic recommendations for vegetable cracker, cooking spices, uleg chili sauce, and burger buns are growth, seeking for dominance and maximum investment.
\end{abstract}

Keywords: portfolio analyzing, crackers, cooking spices, uleg chili sauce, burger buns

\begin{abstract}
ABSTRAK
PT Sekar Laut, Tbk (PTSL) merupakan perusahaan lokal yang memiliki tiga unit bisnis yaitu unit bisnis snack kerupuk, food seasoning dan private label. PTSL diharapkan mampu meningkatkan keunggulan kompetitifnya sehingga mampu bersaing dengan perusahaan global yang masuk ke Indonesia, dikarenakan potensi Indonesia. Tujuan dari penelitian ini adalah 1) analisis posisi relatif PTSL terhadap market leader perusahaan industri snack dan food seasoning, 2) analisis metode Life Cycle unit bisnis PTSL, 3) analisis posisi kategori produk utama PTSL dalam matriks portofolio, 4) memberikan rekomendasi alternatif strategi pengembangan portofolio per kategori produk PTSL. Metode yang digunakan dalam penelitian ini adalah analisis deskriptif. Alat analisis yang digunakan dalam penelitian ini adalah matriks BCG, model Life Cycle, IFE, IFI dan matriks GE. Hasil analisis matriks BCG menunjukkan bahwa posisi relatif unit bisnis snack kerupuk dan food seasoning berada pada kuadran Question Mark. Hasil analisis life cycle unit bisnis kerupuk, food seasoning dan private label, ketiganya berada pada fase Growth. Hasil analisis portofolio menggunakan matriks GE memperlihatkan bahwa kategori produk kerupuk udang dan kerupuk ikan berada pada kuadran Pertumbuhan Selektif. Kategori produk kerupuk sayur, sambal uleg, bumbu siap saji dan roti burger, semua berada pada kuadran Investasi dan Pertumbuhan. Rekomendasi strategi untuk kerupuk udang dan kerupuk ikan adalah identifikasi segmen yang tumbuh, investasi agresif dan mempertahankan posisi. Rekomendasi strategi untuk kerupuk sayur, bumbu dapur, sambal uleg dan roti burger adalah tumbuh, mencari dominansi dan investasi maksimum.
\end{abstract}

Kata kunci: analisis portofolio, snack kerupuk, sambal uleg, bumbu siap saji, roti burger

\footnotetext{
${ }^{1}$ Corresponding author:

Email: omisetiawan@yahoo.com
} 


\section{INTRODUCTION}

Indonesia is a country that has a potential to be the global market targets due to its population which made it as the world's $4^{\text {th }}$ largest country with a population of 237 million in 2012. Indonesia is also able to maintain a stable macroeconomic environment, and based on the data obtained from BPS, at the end of 2012, the GDP of Indonesia grew by $6,23 \%$ and by $5,7 \%$ at the end of 2013. Another interesting potential of Indonesia is that the number of middle class population increased sharply. The data obtained from the Indonesian Consumer Goods and Retail Report, EIU stated that in 2012, the population of middle class Indonesia reached 45 million, and by 2030 it is estimated to rise by $300 \%$ reaching 135 million people where almost $80 \%$ of household income in Indonesia will reach over US $\$ 5.000$ a year in 2017 .

Due its potential to become the global market target, the local companies should increase the potentials for their company in order to have a competitive edge against the competition with global companies. Lack of ability to market and create value-added brands and has caused most of the local companies to experience difficulties to grow. This condition has been experienced by PT Sekar Laut, Tbk. (PTSL) as a local Indonesian company which still exists, although it was founded in 1966 with its initial business as a manufacturer of prawn crackers. PTSL currently has three focused business units, namely crackers, cooking spices and private label. The snack cracker business unit has three main product categories namely shrimp crackers, fish crackers and vegetable crackers. The cooking spices business unit has two main product categories of ready product spices and uleg chili sauce launched at the beginning of 2013. The business unit with a private label product category is burger buns in which it produces burger buns for several international franchises such as McDonald, KFC, Burger King, and AW.

Snack cracker business unit experienced a downward trend in sales growth in the period of 2011/10 where sales growth reached $40 \%$, while in the period of $2013 / 12$, the growth was only $22 \%$. This business unit usually contributes $>80 \%$ of the total sale; however, in 2013 it only contributed $70 \%$ of total sales. The contribution of cooking spices business unit in 2013 increased sharply by $21 \%$ compared to that in the year 2012 which amounted to only $6 \%$, but the sales growth increased significantly by $451 \%$ when compared to the previous period, due to the launching of a new product category i.e. uleg chilie sauce. This high increase has directed PTSL management to focus on investment in the business unit of cooking spices instead of cracker snack in the next 5 years. The management decision needs to be supported by an analysis to see the potential of the business unit of cooking spices so that it as a priority allocation of resources as well as how potential cracker business unit as the backbone of the company, also the potential of private label business unit. The company also needs to know how to position the industry attractiveness and business strengths of each major product category PTSL. Based on the description above, this research needs to be conducted to address the following issues:

1. What is the relative position of snack cracker and cooking spices business unit portfolios against their competitors?

2. How is the life cycle of the business units of snack crackers, cooking spices and private label?

3. What is the relative position of the categories of crackers, ready made chili seasoning and burger buns in the portfolio matrix?

4. What alternative strategies can be used by PTSL for the development of portfolios of product categories of prawn crackers, fish crackers, vegetable crackers, uleg chili sauce, ready made cooking spices, and burger buns?

The objectives of the research were as follows: 1) Analysis on the relative position of snack cracker and cooking spices business unit portfolios against their competitors; 2) analysis on the life cycle of the business units of snack crackers, cooking spices and private label; 3) analysis on the relative position of the categories of crackers, ready made chili seasoning and burger buns in the portfolio matrix; 4) formulation of alternative strategies that can be used by PTSL for the development of portfolios of product categories of prawn crackers, fish crackers, vegetable crackers, uleg chili sauce, ready made cooking spices, and burger buns.

The scope of this study focused on the analysis of the relative positions of business units of cracker snacks and cooking spices against the the market leader. This study also analyzed the Life Cycle model for the business units of cracker snacks, cooking spices and private label, and this study also analyzed the portfolio analysis of product categories of prawn crackers, fish crackers, vegetable crackers, ready made food seasong, 
uleg chili sauce and burger buns as well as the strategy development portfolio. The recommendations for the portfolio development strategy are provide; however, the implementation and evaluation phases will be entirely conducted by the PTSL management.

This research is expected to provide integrated recommendations from a number of analysescarried out. The BCG matrix analysis result shows the relative position of the business unit if compared with the main competitors supported by the result of the internal data analysis using the Life Cycle model, directing the strategic recommendations based on the GE matrix GE result to become more precise. The previous research used the IFE, IFI and GE matrixes to provide the strategic recommendations without analyzing the position against competitor products or product stages in its life cycle. Another study was also conducted with different product categories using the same analytical tools of BCG matrix, Life Cycle model, IFE, IFI and GE matrix; nevertheless, the recommendation was based on the GE matrix since the analysis included external and internal factors.

\section{METHOD}

Data types and sources in this study were primary and secondary data in the qualitative and quantitative forms obtained from the PTSL management, literature studies, reports/ articles. The primary data of the collection of information were obtained through questionnaires filled in by the internal respondents of the management. The secondary data such as sales data and management policies were obtained from the annual report and from the PTSL management.

This study is a direct assessment of the case study occurring in PTSL in the development of its portfolio of product categories. Sampling techniques were carried out with a non-probability sampling approach (sampling without opportunities) through the judgment/ purposive sampling technique (intentional sampling). This technique was used to determine the individuals who would become the respondents for the in-depth interviews.

The performance of the company was analyzed using the BCG matrix and analysis model Life Cycle. Shaw (2012) states that the products in BCG matrix are directly related to the model phase of Life Cycle. The formulation of the strategy was based on GE matrix, after the analysis of the relative position of each product category was conducted. The formulation of this strategy involves the business unit information from the analysis results of the BCG matrix and Life Cycle model to strengthen the basis of decision strategies. The GE matrix analysis results are used as the basis for the formulation of strategies since they represent internal and external factors. The managerial implication of GE matrix is a long-term strategy and focused on the priority of the allocation of resources to the business portfolio.

A strategy is a plan that is united, broad and integrated and connects the superiority of the corporate strategy to the environmental challenges, and it is designed to ensure that the main goal of the company is properly implemented by the organization. Business strategies can include geographic expansion, diversification, acquisition, product development, market penetration, divestitures, employee rationalization, liquidation and joint ventures. The strategies require decisions from the top-level management and great resources of the company, and they influence the prosperity of the company in the long term and in its future orientation. These strategies have multifunctional and multidimensional consequences as well as the need to consider external and internal factors faced by the company (David, 2013).

Wheelen and Hunger (2012) define the management strategy as a series of managerial decisions and actions that determine the long term performance of a company or organization; moreover, it is an ongoing and gradual process that aims to keep the organization as a whole in accordance with the environment.

Portfolio is the ability of the company to use shared costs and appropriate allocation of the existing funds, and in some cases, it is termed as "giving new money" to one or several controlled areas (David et al. 2008). The portfolio analysis can be used by the manager in evaluating the company with diverse businesses so that it can allocate resources appropriately and obtain a balanced and growing portfolio (Carpenter and Sanders, 2009).

According to Wheelen and Hunger (2012), the portfolio analysis is commonly used in the formulation of strategies because they have the advantages of: 
- Encouraging the top management to evaluate each SBU (strategic business unit) separately, set and allocate resources to each SBU properly.

- Encouraging the use of information derived from an external company in decision making by the management.

- Providing financial information at the time the company will carry out expansion and growth

- Facilitating the interpretation of the position of a product or SBU

Sumarno (2011), Rachmawati (2012) and Dung (2012) analyzed the product portfolios by using the analytical tools of BCG and GE matrixes and PLC model. The PLC model was used in forecasting and innovating products like research conducted by Yoo (2010), Partner, Chauduri and Chowdhury (2012), Bakker (2013), Sharma (2013) and Kaldasch (2015). Amatulli, Caputo and Guido (2011), Mokaya, Wakhungu and Gikunda (2012) and Sun (2015) conducted a study in the application of GE matrix strategy for the product portfolio. Muzi and Wong (2013) conducted a study on Haier business portfolio and Khan et al. (2015) conducted a portfolio analysis for Apple Inc. using PEST, SWOT and BCG matrix analysis tools.
Udo-Imeh, Edit and Nani (2012), Makarova and Krizanov (2013) used a matrix analysis tool for BCG and GE in analyzing the product portfolios, while Srivastava and Prakash (2011) and Debrecht and Levas (2014) used the BCG matrix. Shaw (2012) created marketing strategy planning by using SWOT, PLC and BCG matrix analysis tools. Pham et al (2015) used analyses of IFE, EFE, IE matrix, SWOT and QSPM to formulate a strategy for Batik Tulis.

PTSL is required to conduct analyses on the focused business units and product categories and to determine appropriate development strategies for them. The concept of the determination of the strategy, according to David (2013), consists of three stages. The first stage is the input stage which can be carried out through analysis on the internal and external factors or through the collection of both supporting primary and secondary data. The second stage is the matching stage which is a continuation of the first stage of the process where information is processed and then mapped into some analysis models relevant to this research study in which in this study the mapping will be conducted in the BCG and GE matrixes and in the form of PLC diagram. The third stage is the decision stage which is the results of thorough analyses of several analysis tools used to produce alternative strategies as presented in Figure 1.

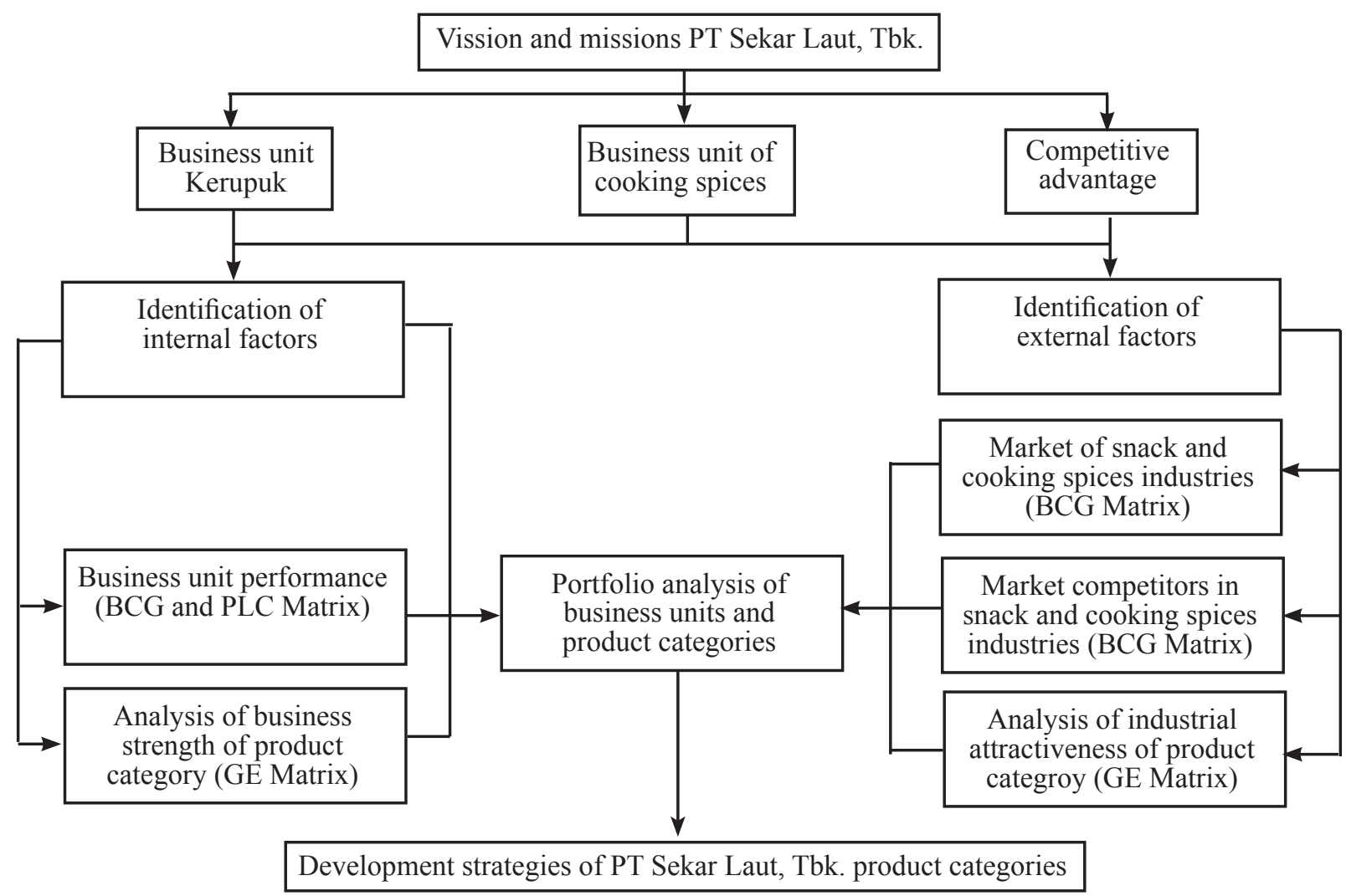

Figure 1. Conceptual framework 


\section{RESULTS}

The analysis results of each business unit and product category based on the method used are as follows:

\section{The position of Business Unit of PTSL in the BCG Matrix}

The basic principle of analysis using BCG matrix is to divide an area with two vertical and horizontal lines into four areas (quadrants). The horizontal line depicts the relative position of the market share held by the company while the vertical line indicates the market growth rate. Each quadrant illustrates the position of alternative products and product development strategies that should be carried out by the company (Grunic and Kuhn, 2011).

- Stars quadrant, representing business units or product lines that have high industrial appeals and a strong competitive position.

- Dogs quadrant, representing the business units or business lines that have a low industrial attractiveness and a weak competitive position as well.

- Question marks quadrant, representing the business units that have high industrial appeals but have a weak competitive position.

- Cash cows quadrant, representing business units or product lines that have low industrial attractiveness but have a strong competitive potential

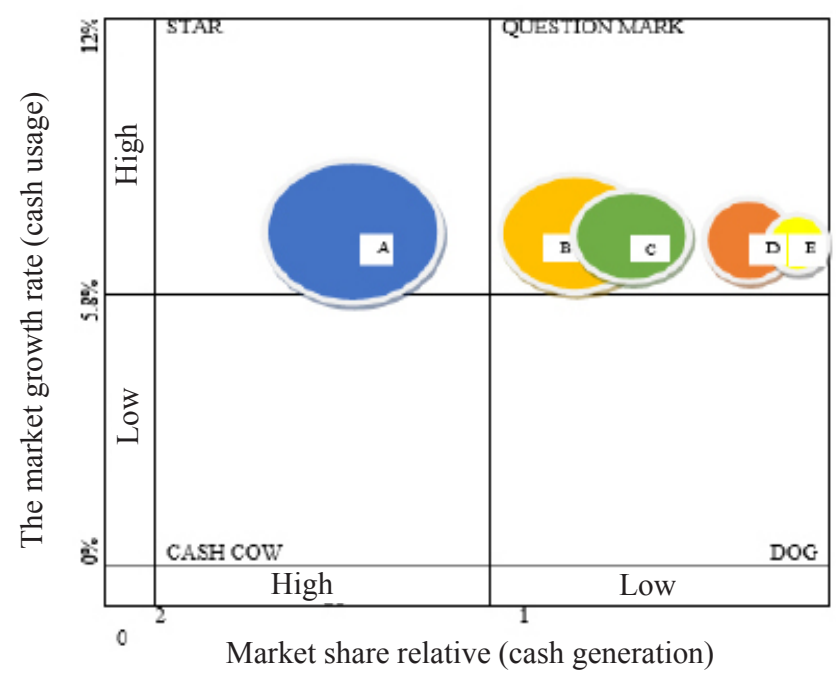

Description:
A. Garuda Food
D. Tiga Pilar Sejahtera
B. Indofood
E. PTSL
C. Siantar Top

Figure 2. Position of cracker business unit of PTSL in BCG Matrix a. Business unit of cracker Snacks

Garudafood snack industry is a market leader that is in star quadrant while Indofood as the best competitors is still in the question mark quadrant but close to the Star quadrant. Other competitors such companies Siantar Top, Tiga Pilar Sejahtera (TPS) is also located question mark quadrant like PTSL with its Finna snack crackers. Mapping of PTSL company portfolio and its competitors at BCG matrix can be illustrated in Figure 2.

\section{b. Business unit of cooking spices}

Heinz ABC, the market leader for the cooking spices industry, star quadrant, while Unilever, the best competitor of Heinz ABC is in question mark quadrant but close to Star quadrant. Other competitors such as Indofood Company is also located in question mark quadrant; moreover, PTSL with its Finna cooking spices is also located in question mark quadrant with its relatively very small market share of 0,02 compared to that of Heinz ABC as the market leader in cooking spices industry. Mapping of portfolio of PTSL Finna cooking spices and its competitors in BCG matrix can be illustrated in Figure 3.

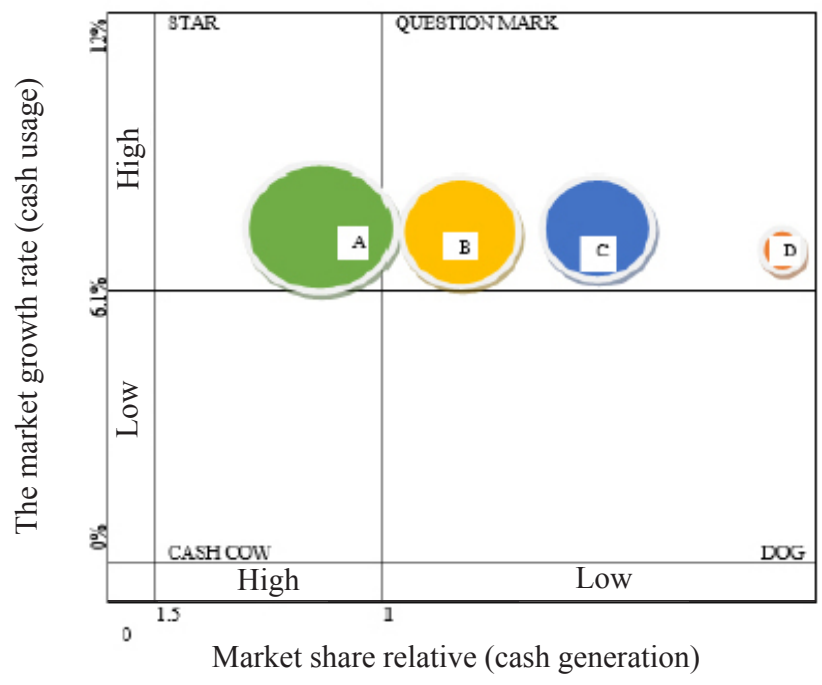

Description:
A. Garuda Food
D. Tiga Pilar Sejahtera
B. Indofood
E. PTSL
C. Siantar Top

Figure 3. Position of business unit of PTSL cooking spices in BCG Matrix 


\section{Life Cycle Analysis Method}

Kotler (2011) defines life cycle analysis model in an attempt to identify stages of sales of products in which at each stage different opportunities and problems mainly related to product marketing strategy are encountered. This is expected to be able to recognize stages that will help the company formulate a good marketing strategy.

Life cycle analysis of PTSL business units of crackers, cooking spices and private label PTSL aims to determine the maturity level of each business unit whether it is in a phase of introduction, growth, maturity or decline. Shaw (2012) states that a business unit in BCG matrix is directly related to the phase of life cycle analysis model. Business units which are in quadrants of question mark and star in BCG matrix are in the early phases of the life cycle with recommended strategies of introduction and growth. Recapitulation of the life cycle model analysis can be seen in Table 1. The mapping results can be seen in Figure 4.

Table 1. Analysis result of life cycle model

\begin{tabular}{lcc}
\hline \multirow{2}{*}{ Business unit } & \multicolumn{2}{c}{ Maturity product } \\
\cline { 2 - 3 } & $\Delta$ Growth & Phase \\
\hline Crackers & $(+)$ & Growth \\
Cooking spices & $(+)$ & Growth \\
Private label & $(+)$ & Growth \\
\hline
\end{tabular}

\section{Portfolios of Product Categories of Crackers, Cooking spices and Burger Buns in the GE Matrix}

Hax and Majluf (1991) states that GE matrix has two axes, namely horizontal and vertical axis. The horizontal axis of the matrix attractiveness of the industry which is a subjective assessment is based on the external factors that cannot be controlled by the company, and this was aimed at describing the industry structure and competence in which the business or product unit operates. This includes market size, market growth rate, industry cycle, competition structure, barriers for the entry of the industry, industry profitability, technology, inflation, regulations and policies, human resource availability, and social, political, environmental and legal issues.

The vertical axis shows the strength of the business which is a subjective assessment based on the key success factors that are fully controlled by the company. This determines the position of a business or product unit in the industry such as market share, salesperson, marketing, customer service, $R \& D$, production processes, distribution channels, financial resources, image, product line breadth, product quality and management competencies. The data processing results of the research conducted on each of product categories in the business units of crackers, cooking spices and private labels can be delivered in detail.

\section{a. Finna prawn crackers}

The measurement results of the industry attractiveness and business strength of the Finna prawn cracker product categories show that the total value of the attractiveness of the industry for the product is at 3,55 (intermediate category) and the total value of the business strength of this product amounted to 3,77 (high category). This puts the product in the GE matrix of quadrant II that is in a selective growth position.

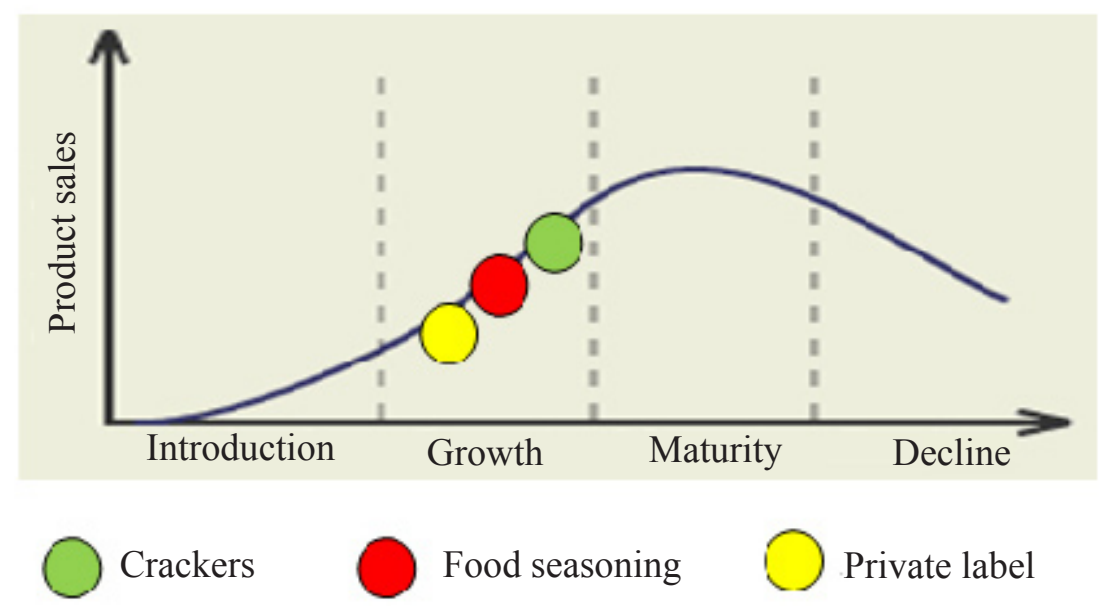

Figure 4. Mapping of life cycle of business units of crackers, cooking spices and private label of PTSL 


\section{b. Finna fish crackers}

The measurement results of the industry attractiveness and business strength of the Finna fish cracker product categories show that the total value of the attractiveness of the industry for the product is at 3,65 (intermediate category) and the total value of the business strength of this product amounted to 4,28 (high category). This puts the product in the GE matrix of quadrant II that is in a selective growth position.

\section{c. Finna vegetable crackers}

The measurement results of the industry attractiveness and business strength of the Finna vegetable cracker product categories show that the total value of the attractiveness of the industry for the product is at 3,69 (intermediate category) and the total value of the business strength of this product amounted to 3,87 (high category). This puts the product in the GE matrix of quadrant I that is in investment and growth position.

\section{d. Finna instant cooking spices}

The measurement results of the industry attractiveness and business strength of the instant cooking spices product categories show that the total value of the attractiveness of the industry for the product is at 3,74 (intermediate category) and the total value of the business strength of this product amounted to 4,25 (high category). This puts the product in the GE matrix of quadrant I that is in investment and growth position.

\section{e. Finna uleg chili sauce}

The measurement results of the industry attractiveness and business strength of the Finna uleg chili sauce product categories show that the total value of the attractiveness of the industry for the product is at 3,74 (intermediate category) and the total value of the business strength of this product amounted to 4,27 (high category). This puts the product in the GE matrix of quadrant I that is in investment and growth position.

\section{f. Burger buns}

The measurement results of the industry attractiveness and business strength of burger bun product categories show that the total value of the attractiveness of the industry for the product is at 3,88 (intermediate category) and the total value of the business strength of this product amounted to 4,28 (high category). This puts the product in the GE matrix of quadrant I that is in investment and growth position. The positions of the PTSL product categories in GE Matrix are shown in Table 2.

Mapping of each product category in GE matrix can be seen in Figure 5. The order of the size of the circle leads to the order of the percentage contribution of total sales of each product category.

\section{Managerial Implications}

From the analysis results from BCG matrix, it can be seen that the position of PTSL business units of snack crackers and cooking spices is among the market leaders of snack and cooking spices industries that is in question mark position, which means that PTSL business units of snack crackers and cooking spices are in a high growth market but with a relatively very low market share. This is confirmed by the results of the analysis of life cycle models for these business units in which they are located in the growth phase; in addition, the private label business unit is also located in the growth phase.

Table 2. Position of PTSL product categories in GE Matrix

\begin{tabular}{|c|c|c|c|c|c|c|c|}
\hline \multirow{2}{*}{ Product category } & \multicolumn{3}{|c|}{ Attractiveness of the industry } & \multicolumn{3}{|c|}{ Business strength } & \multirow{2}{*}{$\begin{array}{l}\text { Position of } \\
\text { GE Matrix }\end{array}$} \\
\hline & Value & Category & Rank & Value & Category & Rank & \\
\hline Prawn crackers & 3,55 & Intermediate & 6 & 3,77 & High & 6 & II \\
\hline Fish crackers & 3,66 & Intermediate & 5 & 4,28 & High & 1,5 & II \\
\hline Vegetable crackers & 3,69 & High & 4 & 3,87 & High & 5 & I \\
\hline Cooking spices & 3,74 & High & 2.5 & 4,25 & High & 4 & I \\
\hline Uleg chili sauce & 3,74 & High & 2.5 & 4,27 & High & 3 & I \\
\hline Burger buns & 3,88 & High & 1 & 4,28 & High & 1,5 & I \\
\hline
\end{tabular}




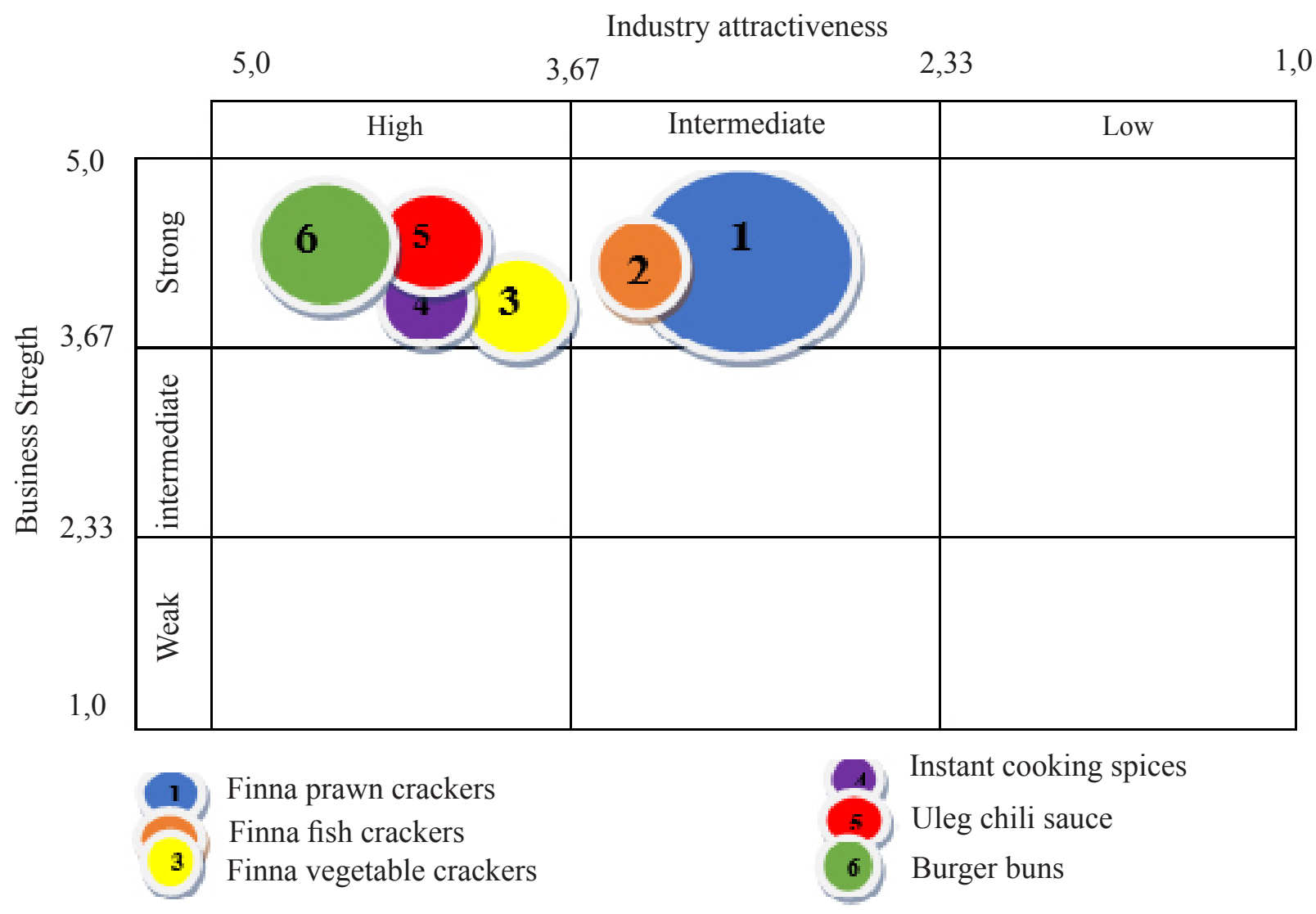

Figure 5. Mapping of PTSL product categories in GE Matrix

The third position this business unit has the opportunity to grow and develop to be successful as long as all the available resources of the company's investments are managed effectively and efficiently in the development. Given the fact that the company's resources are limited, they must be used optimally for the identification and development of the internal factors or strong products so that it can be the competitiveness strength of the company to make this business unit as a market leader. The analysis results of the PTSL six major product categories using GE matrix generating alternative strategies such as in Table 3.

Determination of the prioritization of resource management strategy is determined by the recommendations of GE matrix generating alternative strategies as follows:

\section{Product category strategy of Finna prawn crackers}

The rapid development trend of healthy snacks due to awareness of the importance of healthy food which is quite high among the Indonesian people, especially for the urban upper middle class has directed the PTSL management to invest for the product category of prawn crackers in this growing segment. The main attraction of this industry is technology and consumer influence; therefore, the management can focus more on aggressive investment in technology improvement and purchase of machinery, and it can also innovate with a focus on product development of RTE (ready to eat) prawn crackers and prepare for other resources, including labor, promotion costs and distribution channel addition. Packaging must also follow the development and reflects premium quality of snack products. PTSL is also directed to maintain and improve the position with a market share of $1 \%$ in the snack industry, which is based on in-depth interviews with the marketing team where Finna cracker product has a $75 \%$ market share in the cracker industry.

\section{Product category strategy of Finna fish crackers}

Trend for healthy snacks in the Indonesian society, especially in the urban middle class has directed PTSL to invest in terms of the selection of high-technology machines to produce healthy snacks preferred by consumers, to innovate so that product differentiation can be more recognized and enjoyed, and follow the development trend of snack packaging for the middle class consumers. 
The management can focus more on aggressive intensive to improve technology by the purchase of high-quality machine for the development of innovative types of fish, RTE (ready to eat) fish cracker products and preparation of other resources, including labor, promotion costs and additional distribution channels. PTSL business major strengths for this product category include high-quality products, well known Finna brand and product differentiation which determine the success of the company in healthy competition with its competitors. Its position as the market leader in the cracker industry should be maintained, and based on the in-depth interviews with the marketing team, Finna cracker product Finna has $75 \%$ market share in the industry although its market share is only $1 \%$; therefore, it should be improved as well.

3. Product category strategy of Finna vegetable crackers

The PTSL management has been directed to invest in the growing middle class segment by adding machine and investing in a new factory in Semarang to increase the tonnage production volume of the vegetable crackers commencing in early 2014 . There are many home industries that produce these types of crackers but without standardized product quality in terms of raw materials, hygiene and strong flavor as well as local distribution. PTSL with its existing resources in the form of machinery, labor and innovation may surpass the weaknesses of the local companies of vegetable crackers and dominate the market.

\section{Product category strategy of Finna instant cooking spices}

Priority of investment has directed PTSL management to grow and increase investments by looking for superior products that could compete with its competitors and generate high profits that could support other products in the developing world. The company also needs to increase brand awareness for the product category of Finna instant cooking spices besides the widely known Finna crackers. PTSL management is recommended to seek domination by focusing superior instant cooking spices products with the best local distinctive flavors, with the promising earnings to be supported more in terms of resources. For example, rendang and Soto seasonings are very commonly known by the community but they are difficult and take a long time to prepare.
5. Product category strategy of Finna uleg chili sauce

A very significant increase in the number of lowermiddle class of the urban population of Indonesia where both husband and wife work has directed toward the prospect of uleg chilled sauce that will be developed following the trend of urban middle class couples. The PTSL management has been aware with this condition and conducted research to produce home-made sauce, invested additional machine to produce chili sauce with traditional flavors and expanded the factory in Sidoarjo. R \& D team is also directed to develop some new products of traditional chilled sauces from the existing products.

Dominance that can be recommended is to distribute the uleg shrimp paste chili sauce sachets to the traditional and small grocery store channels. The category of uleg chili sauce is prioritized for healthy competition to raise awareness of the existing Finna uleg chilled sauce through promotions of ATL and BTL by taking into account healthy profits.

\section{Product category strategy of burger buns}

The analysis result of GE matrix has directed PTSL to add its factory machine capacity with high technology to balance its production with its market growth rate of fast food retail, especially in the eastern part of Indonesia to support the needs of burger bun products in the region.

\section{CONCLUSIONS AND RECOMMENDATIONS}

\section{Conclusions}

The conclusions that can be drawn from this study state that: (1) the results of the analysis using BCG matrix indicate that the relative positions of business units of crackers and cooking spices are in question mark quadrant, which means that these products are in high market growth; however, they have a relatively very low market share; (2) the analysis results of the life cycle model indicate that the business units of crackers, cooking spices and private label are in the growth phase. The results of both analyses are in accordance with the recommendations that the business unit quadrant based on BCG matrix analysis results is in line with the business unit phase in life cycle model analysis. These results direct the business units to have 
the opportunity to grow and develop to be successful business units provided that all available resources for the investment company are managed effectively and efficiently; (3) The analysis results of portfolios of product categories GE matrix recommends priority investment strategy for each product category in the main business units of PTSL. Product categories of prawn crackers and fish crackers are in Selective growth quadrant while the product categories of vegetable crackers, uleg chili sauce, instant cooking spices, and burger buns are in the Investment and growth quadrant; (4) Recommendation strategies for product categories of prawn crackers and fish crackers are identifications of the growing segments, aggressive investments and position maintenance. Strategies recommended for the product categories of vegetable crackers, uleg chili sauce, instant cooking spices and burger buns are growing, seeking domination, and obtaining maximum investment. These strategy recommendations are expected to assist the PTSL management so that it can increase the opportunities to add market share in both the industries of snacks and cooking spices and are also able to follow the growth of fast-food restaurants for the burger bun product category.

\section{Recommendations}

This research has recommended an integrated strategy from the several analytical tools, which distinguishes it from the previous studies. Based on the recommendations given for this research, it should be carried out with a more detailed analysis of the portfolio by exploring the margins and profitability for every business unit and product category so that more in-depth recommendations could be given related to the investment priorities so that the continuity of the company is guaranteed. Life cycle analysis should also be directed to obtain data for every product category so as to determine its phase so that recommendations for investment priority strategies can become sharper because they are combined with the life cycle phase of each product category. The following study is expected to be directed toward the market side for detailing strategies that have been formulated in this study, and this is also expected focus on supply chain related to the availability of primary fishery and agricultural raw materials which are fluctuated. Also, the following research can study what strategies PTSL can apply to export its products abroad. The writer becomes highly motivated because the research was published in the journal and becomes the basis to carry out other research and publish the results.

\section{REFERENCES}

Amatulli C, Caputo T, Guido G. 2011. Strategic Analysis through the General Electric/McKinsey Matrix: An Application to the Italian Fashion Industry. International Journal of Business and Management 6(5):61-68. http://dx.doi. org/10.5539/ijbm.v6n5p61.

Bakker P. 2013. The Life Cycle of a Free Newspaper Business Model in Newspaper-Rich Markets. Journalistica NR 1: 33-48.

Carpenter MA, Sanders WG. 2009. Strategic Management A Dynamic Perspective Concept and Cases. 2nd Ed. London: Prentice-Hall International.

David FR. 2013. Strategic Management Consept and Cases 14th Edition. England: Pearson Education Limited.

David PK, Russell DS, Justin B. 2008. PortfolioAnalysis Methods for Assessing Capability Options. California: Rand Corporation.

DebrechtD, Levas M.2014. Using theBoston Consulting Group Portfolio Matrix to Analyze Management of a Business Undergraduate Student Program at a Small Liberal Arts University. Journal of Higher Education Theory and Practice 14(3): 65-69.

Dung VA. 2012. Brand and Product Divestiture: A Literature Review and Future Research Recommendations. Journal of Management \& Marketing Challenges for the Knowledge Society 7(1): 107-130.

Grunig R, Kunh R. 2011. Process-based Strategic Planning. 9th Ed. New York: SpringerHeidelberg.http://dx.doi.org/10.1007/978-3642-16715-7.

Hax AC, Majluf NS. 1991. The Strategy Concept and Process: A Pragmatic Approach. New Jersey: Prentice-Hall.

Kaldasch J. 2015. 2015. The Product Life Cycle of Durable Goods. British Journal of Economics, Management and Trade 10(2):1-17. http:// dx.doi.org/10.9734/BJEMT/2015/20395. 
Kotler P. 2011. Marketing Management Millenium Edition. 10th Ed. New Jersey: Prentice-Hall.

Masarova G, Krizanova A. 2013. Innovation of Company's Product Portfolio in the Field of Construction Industry in Slovak Condition. Journal of the 7th International Days of Statictics and Economics, Prague. September 19-21, 2013: 966-976.

Mitra S, Chaudhuri SRB, Chowdhury S. 2012. Product Prioritization Matrix: A Strategic Tool, To Plan Brand Promotion Priority for Optimized Business Growth. International Journal of Management \& Information Technology 1(3): 80-88.

Mokaya SO, Wakhungu B, Gikhunda RM. 2012. The Application of MKinsey Matrix in Determination of Route Attractiveness and Resource Allocation in Kenya Airways. International Journal of Humanities and Social Science 2(3): 259-268.

Muzi HE, Wong KC. 2014. An Analyrical Study on Strategic Management of Haier. Journal of Contemporary Management 128(2): 1-14.

Khan UA, Alam MN, Alam S. 2015. A Critical Analysis of Internal and External Environment of Apple Inc. International Journal of Economics, Commerce and Management 3(6):955-961.

Rahmawati S. 2012. Strategi Pengembangan Portofolio Produk Berdasarkan Prinsipal Pada Perusahaan Distributor PT XYZ [tesis]. Bogor: Program Manajemen dan Bisnis, Institut Pertanian Bogor.

Sharma N. 2013. Marketing Strategy on Different Stages PLC and Its Marketing Implications on FMCG Products. International Journal of Marketing, Financial Services \& Management Research 2(3): 121-136.
Shaw EH. 2012. Marketing Strategy from the Origin of the Concept to the Development of a Conceptual Framework. Journal of Historical Research in Marketing 4(1): 30-55.http://dx.doi. org/10.1108/17557501211195055.

Srivastava R, Prakash A. 2011. Growth-Share Matrix as a Tool for Potfolio Planning: Evidence from the Indian Telecummunication Services Industry. The IUP Journal of Business Strategy 8(2): 22 33.

Sumarno. 2011. Analisis Portofolio Produk Tabungan dan Strategi Pengembangannya (Studi Kasus pada PT bank Bukopin, Tbk) [tesis]. Bogor: Program Manajemen dan Bisnis, Institut Pertanian Bogor.

Sun Q. 2015. Evaluating Sustainable Urbanization and Coordinated Development - A case study of Liaoning in China. International Journal of Smart Home 9(4): 73-84. http://dx.doi. org/10.14257/ijsh.2015.9.4.08.

Suryani IE, Anggraeni L, Suryadi U. 2015. Strategy Formulation for Developing Batik Tulis. Indonesian Journal of Business and Entrepreneurship 1(1): 23-31. http://dx.doi. org/10.17358/IJBE.1.1.23

Udo-Imeh PT, Edet WE, Anani RB. 2012. Portfolio Analysis Models: A Review. European Journal of Business and Management 4(18): 101-117.

Wheelen TL, Hunger JD. 2012. Strategic Management and Business Policy 13th Edition. New Jersey: Prentice-Hall.

Yoo CS. 2010. Product Life Cycle Theory and the Maturation of the Internet. Norton University of Law 104(2): 641-670. 